\title{
BUKTI TIDAK LANGSUNG DALAM PENYELESAIAN SENGKETA KARTEL
}

\author{
Kurniawan \\ Fakultas Hukum Universitas Mataram \\ NTB, Indonesia \\ Email: kurniawan3377@gmail.com
}

\begin{abstract}
Abstrak
Tujuan penelitian ini adalah untuk mengetahui bagaimana kedudukan bukti tidak langsung dalam penyelesaian Perkara Kartel di Indonesia. Bukti tidak langsung dalam UndangUndang No. 5 Tahun 1999 tentang Larangan Praktek Monopoli dan Persaingan Usaha Tidak Sehat dalam penyelesaian sengketa Kartel adalah sebagai bukti tambahan dan bukan merupakan bukti utama. Untuk memecahkan dan menyelesaikan kasus-kasus kartel di Indonesia, Komisi Pengawas Persaingan Usaha (KPPU) tidak bisa hanya mengandalkan bukti tidak langsung saja. Hal ini karena bukti tidak langsung dalam Undang-Undang Persaingan Usaha merupakan bagian dari bukti petunjuk saja, sehingga yang termasuk dalam alat bukti adalah bukti petunjuk, sedangkan bukti tidak langsung berupa bukti komunikasi atau hasil analisis ekonomi digunakan sebagai bukti tambahan untuk memperkuat alat bukti yang lain.
\end{abstract}

\section{Kata kunci : Bukti tidak langsung; Sengketa; Kartel.}

\begin{abstract}
The purpose of this study is to find out how the position of indirect evidence in the settlement of the Cartel Case in Indonesia. Indirect evidence in Law No. 5 of 1999 concerning Prohibition of Monopolistic Practices and Unfair Business Competition in Cartel dispute resolution is as additional evidence and not the main evidence. To solve and resolve cartel cases in Indonesia, the Business Competition Supervisory Commission (KPPU) cannot rely solely on indirect evidence. This is because indirect evidence in the Business Competition Act is part of evidence evidence only, so what is included in evidence is evidence evidence, while indirect evidence in the form of communication evidence or economic analysis results are used as additional evidence to strengthen other evidence.
\end{abstract}

\section{Keyword : Indirect evidence; Dispute; Cartel.}

\section{A. PENDAHULUAN}

Bukti tidak langsung masih terus menuai perdebatan pada rezim hukum persaingan usaha, khususnya terkait penanganan sengketa kartel. Terdapat pihak yang setuju dengan penggunaan jenis pembuktian ini, tapi ada juga pihak lain yang menolak menggunakan bukti tidak langsung. Komisi Pengawas Persaingan Usaha (KPPU) termasuk pihak yang setuju dan sering menggunakan jenis bukti tidak langsung, khususnya dalam penangnan perkara kartel.

Pasal 35 huruf a Undang-Undang No. 5 Tahun 1999 menyatakan jika pelaku usaha melanggar Pasal 4 sampai dengan Pasal 16, maka KPPU akan melakukan penilaian terhadap perjanjian yang dapat mengakibatkan terjadinya Praktik Monopoli dan atau Persaingan Usaha Tidak Sehat. Berdasarkan pasal tersebut, pelaku usaha yang terindikasi melakukan kartel, maka yang harus dinilai oleh KPPU adalah perjanjiannya karena perjanjian inilah yang akan menjadi alat bukti dari adanya kartel. Hanya saja pembuktian dengan menggunakan perjanjian atau kesepakatan tertulis sangat sulit dilakukan.

Dalam perkembangannya, pembuktian kartel menggunakan indirect evidence yaitu buktibukti secara tidak langsung dimana terdapat hasil-hasil analisis ekonomi yang menggunakan

212 Kurniawan| Bukti Tidak Langsung Dalam Penyelesaian.... 
alat-alat ekonomi yang memang secara ilmiah diakui dan bisa menunjukkan korelasi antara satu fakta dengan fakta lain bahwa memang telah terjadi pengaturan perjanjian di dalamnya.

Dari latar belakang di atas, masalah yang diangkat adalah bagaimana kedudukan bukti tidak langsung dalam penyelesaian perkara kartel di Indonesia.

\section{PEMBAHASAN}

Peraturan tentang kartel tersebar dalam berbagai pasal pada Undang-Undang Nomor 5 Tahun 1999 seperti Pasal 5 tentang Kartel Harga (price fixing), Pasal 9 tentang Kartel Wilayah, dan Pasal 11 tentang Kartel Produksi dan Pemasaran. Istilah kartel terdapat dalam beberapa bahasa seperti "cartel" dalam bahasa Inggris dan kartel dalam bahasa Belanda. "Cartel" disebut juga "syndicate" yaitu suatu kesepakatan (tertulis) antara beberapa perusahaan produsen dan lain-lain yang sejenis untuk mengatur dan mengendalikan berbagai hal, seperti harga, wilayah pemasaran dan sebagainya, dengan tujuan menekan persaingan dan atau persaingan usaha pada pasar yang bersangkutan. dan meraih keuntungan ${ }^{1}$.

Perjanjian kartel merupakan salah satu perjanjian yang kerap kali terjadi dalam tindak monopoli. Secara sederhana, kartel adalah perjanjian satu pelaku usaha dengan pelaku usaha pesaingnya untuk menghilangkan persaingan di antara keduanya. Dengan perkataan lain, kartel (cartel) adalah kerja sama dari produsen-produsen produk tertentu yang bertujuan untuk mengawasi produksi, penjualan, dan harga serta untuk melakukan monopoli terhadap komoditas atau industri tertentu. ${ }^{2}$

Anton Muliono dalam Kamus Besar Bahasa Indonesia mengartikan kartel sebagai "(1) Organisasi perusahaan-perusahaan besar (negara dan sebagainya) yang memproduksi barangbarang sejenis. (2) Persetujuan sekelompok perusahaan dengan maksud mengendalikan harga komoditi tertentu. ${ }^{3}$

Pasal 11 Undang-Undang Nomor 5 Tahun 1999 tentang Larangan Praktek Monopoli dan Persaingan Usaha Tidak Sehat menyatakan :

"Pelaku usaha dilarang membuat perjanjian, dengan pelaku usaha saingannya, yang bermaksud mempengaruhi harga dengan mengatur produksi dan atau pemasaran suatu barang dan atau jasa, yang dapat mengakibatkan terjadinya praktek monopoli dan atau persaingan usaha tidak sehat".

Meskipun tidak ada definisi yang tegas tentang kartel di dalam Undang-Undang Persaingan Usaha, namun dari Pasal 11 dapat dikonstruksikan bahwa kartel adalah perjanjian horizontal untuk mempengaruhi harga dengan mengatur produksi dan atau pemasaran suatu barang dan atau jasa, yang dapat mengakibatkan terjadinya praktik monopoli dan atau persaingan usaha tidak sehat. ${ }^{4}$

Pasal 35 huruf a UU No. 5 Tahun 1999 menyatakan bahwa jika pelaku usaha melanggar ketentuan Pasal 4 sampai dengan Pasal 16 UU Persaingan Usaha, maka KPPU akan melakukan penilaian terhadap perjanjian yang dapat mengakibatkan terjadinya praktek monopoli dan atau persaingan usaha tidak sehat. Perjanjian inilah yang akan menjadi alat bukti adanya perjanjian kartel. Masalahnya, pembuktian dengan menggunakan perjanjian atau kesepakatan tertulis sangat sulit dilakukan/dibuktikan. Oleh karena itulah, pembuktian kartel berkembang menggunakan bukti-bukti secara tidak langsung dimana terdapat hasil-hasil analisis ekonomi yang menggunakan tool-tools atau alat ekonomi yang memang secara ilmiah diakui dan

\footnotetext{
${ }^{1}$ Hasim Purba, Tinjauan Yuridis Terhadap Holding Company, Cartel, Trust dan Concern. (On-line) tersedia di http://library.usu.ac.id/download/fh/perda-hasim1.pdf (14 September 2007 ).

${ }^{2}$ Mustafa Kamal Rokan.(2010). Hukum Persaingan Usaha. Jakarta: PT Raja Grafindo Persada, hlm. 105

${ }^{3}$ Johnny Ibrahim.(2007). Hukum Persaingan Usaha. Malang: Bayumedia Publishing, hlm. 230.

${ }^{4}$ Arief Siswanto.(2002). Hukum Persaingan Usaha. Jakarta: Ghalia Indonesia, hlm. 85
} 
bisa menunjukkan korelasi antara satu fakta dengan fakta lain bahwa memang telah terjadi pengaturan di dalamnya. ${ }^{5}$

Namun dalam waktu yang sama, terdapat keterbatasan dalam penggunaan bukti tidak langsung. Bukti tidak langsung berarti bukti tersebut tidak secara langsung mendeskripsikan istilah perjanjian, namun bisa dalam bentuk memfasilitasi adanya perjanjian, atau pertukaran informasi. Pada beberapa kasus, pembuktian tidak langsung melalui pendekatan ekonomi dapat menjadi sumber informasi mengenai adanya kartel. Meskipun demikian, evaluasi spesifik atas informasi yang dimiliki tersebut perlu dilakukan agar tidak disalahartikan. Sebagai contoh adalah kenaikan harga secara simultan yang terdapat di pasar dapat memiliki penjelasan lain selain perjanjian kartel. Pembuktian tidak langsung lebih ditujukan untuk memenuhi standar pembuktian dan memberikan gambaran penguatan akan praktek kartel itu sendiri. Analisa ekonomi yang di berlakukan dalam pembuktian tidak langsung lebih menegaskan dampak terhadap kesejahteraan masyarakat dari praktek kartel untuk mendeteksi adanya kartel. ${ }^{6}$

Terdapat dua macam tipe pembuktian tidak langsung yang meliputi bukti komunikasi dan bukti ekonomi. Bukti komunikasi adalah bukti diamana pelaku kartel bertemu melakukan komunikasi akan tetapi tidak menjelaskan substansi komunikasi tersebut. Sedangkan bukti ekonomi dapat di bagi menjadi bukti prilaku dan bukti struktur. Dari kedua bukti tersebut, bukti komunikasi lebih penting dibandingkan bukti ekonomi. ${ }^{7}$

Penanganan terhadap perkara yang timbul dari tindakan pelaku usaha yang melanggar ketentuan Pasal 11 Undang-Undang Persaingan Usaha, maka KPPU menggunakan pendekatan Rule of Reason untuk menilai perilaku kartel apabila unsur-unsur penilaian kartel telah terpenuhi. Hal ini dapat dilihat dari frase yang dapat mengakibatkan terjadinya praktik monopoli dan atau persaingan usaha tidak sehat. Penggunaan jenis pendekatan ini merujuk kepada praktik di Amerika Serikat, karena di beberapa negara terhadap kartel diterapkan de minimize rule, bahkan per se rule. ${ }^{8}$ Hal yang membedakan rule of reason dari per se rule yaitu bahwa dalam per se rule tidak perlu dilakukan pemeriksaan secara detail apakah suatu perjanjian berdampak pada persaingan usaha tidak sehat, sedangkan rule of reason malah sebaliknya. Dalam rule of reason perilaku di evaluasi menggunakan analisis berdasarkan detail faktanya, sedangkan dalam per se rule pelaku usaha tidak diberikan kesempatan untuk memberikan justifikasi atas perilakunya. ${ }^{9}$

Sementara itu de minimize rule akan membolehkan suatu perilaku kartel apabila perilaku kartel tersebut tidak mengganggu persaingan usaha karna pangsa pasar yang dikuasainya sangat kecil dan kurang dari persyaratan yang ditentukan dalam kebijakan persaingan suatu negara, misalnya 5\%. Oleh karena itu dengan penerapan rule of reason ini maka terhadap perilaku kartel tidak serta merta dinyatakan melanggar ketentuan Pasal 11, masih perlu dilakukan penilaian-penilaian terlebih dulu apakah praktik tersebut menimbulakan dampak terhadap terjadinya praktik monopoli dan persaingan usaha tidak sehat. Sehingga perlu dianalisis apakah perilaku tersebut mengakibatkan kerugian bagi konsumen. ${ }^{10}$ Apabila dampak yang dipersyaratkan itu terpenuhi, maka barulah sanksi dalam Pasal 11 tersebut dikenakan. Jadi inti rule of reason ini adalah diperlukannya suatu pertimbangan apakah kerugian yang ditimbulkan perilaku kartel diimbangi oleh keuntungan atau kemanfaatan lainnya. Apakah kemanfaatan

\footnotetext{
${ }^{5}$ Nawir Messi, Menakar Kekuatan Circumstantial Evidence di Persainga Usaha, hukumonline.com.htm, [diakses pada tanggal 27 Januari 2016]

${ }^{6}$ Riris Munadiya.(2011). “Bukti Tidak Langsung (Indirect Evidence) Dalam Penanganan Kasus Persaingan Usaha”. Jurnal Persaingan Usaha. 5. hlm..168

${ }^{7}$ Ibid., hlm. 174

${ }^{8}$ Ibid.

${ }^{9}$ Ibid.

${ }^{10}$ Ibid.
}

214 Kurniawan | Bukti Tidak Langsung Dalam Penyelesaian.... 
bagi masyarakat konsumen jauh lebih besar daripada kerugian yang dialami karena terjadinya strategi persaingan usaha yang tidak sehat. ${ }^{11}$

Untuk membuktikan bahwa seorang pelaku usaha melakukan pelanggaran terhadap Undang-Undang Persaingan Usaha, Pasal 42 mengatur tentang alat bukti yang digunakan pada pemeriksaan perkara oleh KPPU yaitu, sebagai berikut:

1. Keterangan saksi;

2. Keterangan ahli;

3. Surat dan/atau dokumen;

4. Petunjuk;

5. Keterangan terlapor.

Majelis Komisi KPPU akan menentukan sah atau tidaknya alat bukti dan menentukan nilai pembuktian berdasarkan sekurang-kurangnya dua alat bukti yang sah. Berikut ini diuraikan mengenai macam-macam alat bukti sebagai berikut:

a. Keterangan saksi

Keterangan saksi diperlukan untuk membuktikan ada atau tidaknya suatu pelanggaran yang dilakukan olehterlaporterhadapUndang-UndangPersainganUsaha.Pengertiansaksi adalah setiap orang atau pihak yang mengetahui terjadinya pelanggaran dan memberikan keterangan guna kepentingan pemeriksaan. Dalam laporannya di KPPU, pelapor berusaha untuk mendapatkan saksi-saksi yang dapat membenarkan atau menguatkan dalil laporan yang telah diajukan, dan sebaliknya pelaku usaha terlapor akan berusaha sebisa mungkin untuk melakukan sanggahan melalui saksi-saksi yang mendukungnya.

Keterangan saksiakan menjadi kuat dan menjadi alat bukti yang sah apabila memenuhi ketentuan sebagai berikut:

a) Harus mengucapkan sumpah atau janji;

b) Keterangan saksi yang bernilai sebagai bukti adalah apa yang ia dengar sendiri, ia lihat sendiri dan ia alami sendiri dengan menyebut alasan dan pengetahuannya itu.

c) Keterangan saksi harus diberikan di sidang KPPU;

d) Keterangan seorang saksi saja dianggap tidak cukup. Keterangan seorang saksi saja tidak cukup untuk membuktikan bahwa Terlapor bersalah terhadap perbuatan yang didakwakan kepadanya;

e) Keterangan beberapa saksi yang berdiri sendiri-sendiri tentang suatu kejadian atau keadaan dapat digunakan sebagai suatu alat bukti yang sah apabila keterangan saksi itu ada hubungannya satu dengan yang lain sedemikian rupa, sehingga dapat membenarkan adanya suatu kejadian atau keadaan tertentu.

Pasal73PeraturanKomisiPengawasPersainganUsaha(selanjutnyadisebutPERKOM) Nomor 1 Tahun 2010 tentang Tata Cara Penanganan Perkara, dinyatakan bahwa saksi yang tidak boleh didengar keterangannya adalah keluarga sedarah atau semenda menurut garis keturunan lurus ke atas atau ke bawah sampai derajat ketiga dari terlapor dan atau pelapor, istri atau suami, anak yang belum berusia tujuh belas tahun, atau orang sakit ingatan. PERKOM Nomor 1 Tahun 2010 juga menyatakan jika keterangan dari pihak tersebut diperlukan, maka Ketua Majelis Komisi dapat meminta pihak tersebut untuk didengar keterangannya.

b. Keterangan ahli 
Pasal 1 ayat 20 Perkom Nomor 5 Tahun 2000 menyatakan bahwa yang dimaksud saksi ahli adalah seorang yang memiliki keahlian khusus yang memberikan keterangan kepada Majelis Komisi. Definisi ahli menurut kamus bahasa Indonesia adalah orang yang ahli, paham sekali di suatu ilmu (kepandaian). Pada Perkom No. 1 Tahun 2010 pada Pasal 75 menjelaskan bahwa orang yang dapat menjadi ahli diwajibkan memiliki keahlian khusus yang dibuktikan dengan sertifikat yang berkaitan dengan keahliannya tersebut ataupun memiliki pengalaman yang sesuai dengan keahliannya.

c. Surat dan/atau dokumen

Undang-Undang Persaingan Usaha menyertakan juga surat dan/atau dokumen dalam alat bukti yang sah. Sudah barang tentu keduanya adalah alat bukti yang tertulis. "Alat bukti tertulis adalah segala sesuatu yang memuat tanda bacaan yang dimaksudkan untuk mencurahkan isi hati atau menyampaikan buah pikiran seseorang dan dipergunakan sebagai pembuktian. Akan tetapi tidak mengandung buah pikiran, tidaklah termasuk dalam pengertian alat bukti surat. Suatu gambar, foto yang tidak memuat tanda-tanda bacaan atau buah pikiran, demikian juga dengan denah atau peta, meskipun ada tanda bacanya, tetapi tidak mengandung suatu buah pikiran atau isi hati seseorang adalah hanya sekedar barang atau benda yang untuk meyakinkan saja."

d. Petunjuk

Petunjuk juga merupakan alat bukti yang dapat digunakan dalam pembuktian perkara persaingan usaha. Mengenai alat bukti petunjuk tidak diberikan penjelasan dan kita musti merujuk pada peraturan yang lain. Definisi petunjuk kita dapat merujuk pada Pasal 72 Perkom Nomor 1 Tahun 2010 yang mengatakan bahwa petunjuk merupakan pengetahuan dari Majelis Komisi yang diketahui dan diyakini kebenarannya. Petunjuk dapat dijadikan sebagai alat bukti harus ditentukan kasus per kasus.

e. Keterangan terlapor

Alat bukti terakhir yang diatur dalam Pasal 42 Undang-Undang Persaingan Usaha adalah Keterangan Terlapor. Keterangan terlapor yang dimaksud dalam Undang-Undang ini adalah apa yang terlapor nyatakan didepan Majelis Komisi mengenai perjanjian, perbuatan yang ia lakuakan sendiri, ketahui sendiri, atau alami sendiri. Berdasarkan Perkom Nomor 1 Tahun 2010 Pasal 72 ayat 4 dijelaskan bahwa mengenai keterangan terlapor tidak dapat ditarik kembali kecuali ada alasan yang sangat kuat dan dapat diterima oleh majelis komisi.

Selain alat bukti yang telah dijelaskan diatas, KPPU mengenal terminologi inderect evidence. Indirect evidence menurut Undang-Undang tidak dikenal dalam hukum pembuktian persaingan usaha di Indonesia. Undang-Undang Nomor 5 Tahun 1999 hanya mengenal alat bukti sebagaimana dimaksud dalam Pasal 42. Namun dalam penyelesaian kasus-kasus yang disidangkan KPPU telah menggunakan Indirect evidence sebagai alat bukti salah satunya dalam perkara kartel obat antihipertensi dalam perkara nomor 17/KPPU-I/2010.

Sebagai perbandingan di dalam hukum acara perdata, ditinjau dari sifatnya alat bukti yang disebut dalam Pasal 1866 KUH Perdata, dapat diklasifikasi menjadi alat bukti langsung dan alat bukti tidak langsung. Disebutkan alat bukti langsung, karena diajukan secara fisik oleh pihak yang berkepentingan di depan persidangan. Di samping alat bukti langsung terdapat juga alat bukti tidak langsung, maksudnya pembuktian yang diajukan tidak bersifat fisik tetapi yang diperoleh sebagai kesimpulan dari hal atau peristiwa yang terjadi di persidangan, dimana alat bukti persangkaan dikategorikan sebagai alat bukti tidak langsung ini.

216 Kurniawan | Bukti Tidak Langsung Dalam Penyelesaian.... 
Berikut ini adalah beberapa contoh yang dapat dikategorikan sebagai bukti tidak langsung atau indirect evidence: ${ }^{12}$

1. Catatan tentang banyaknya percakapan telepon antara para pesaing hanya berkenaan dengan banyaknya (beberapa kali) percakapan telepon itu dilakukan bukan mengenai pembuktian substansi percakapan yang melahirkan persekongkolan;

2. Perjalanan menuju tujuan yang sama, misalnya untuk menghadiri konferensi dagang; tanpa membuktikan sama sekali adanya fakta terjadinya persekongkolan;

3. Partisipasi dalam pertemuan, tanpa membuktikan sama sekali substansi pertemuan tersebut yang menghasilkan persekongkolan;

4. Penafsiran atau interpretasi, suatu yang terlarang dalam pembuktian pidana menurut prinsip Hukum Acara Pidana. Pendapat atau rekaan yang diperoleh bukan merupakan bukti;

5. Logika, tidak membuktikan apa yang dilihat, didengar, atau dialami sendiri;

6. Bukti ekonomi yang sangat tergantung kepada metode yang dipergunakan.

Hukum acara perdata maupun hukum acara pidana tidak mengenal pengelompokan istilah alat bukti langsung dan alat bukti tidak langsung. Alat bukti tidak langsung dan alat bukti langsung dikenal dalam hukum acara persaingan usaha. Menurut KPPU, alat bukti tidak langsung dikelompokkan dalam alat bukti petunjuk. Dalam Undang-Undang Persaingan Usaha tidak dijelaskan mengenai alat bukti petunjuk, akan tetapi disebutkan dalam Pasal 72 Ayat 3 Perkom Nomor 1 Tahun 2010 tentang Tata Cara Penanganan Perkara di KPPU, menerangkan bahwa alat bukti petunjuk merupakan pengetahuan Majelis Komisi yang olehnya diketahui dan diyakini kebenarannya. Petunjuk dalam perkara di KPPU dapat diartikan sebagai perbuatan, kejadian atau keadaan, yang karena persesuaiannya, baik antara satu dengan yang lain, maupun dengan laporan dugaan pelanggaran terhadap Undang-Undang Persaingan Usaha, menandakan bahwa telah terjadi pelanggaran terhadap Undang-Undang Persaingan Usaha dan siapa pelakunya. Terdapat banyak definisi mengenai alat bukti petunjuk sebagai alat bukti maupun sebagai sebuah kata. Kamus Besar Bahasa Indonesia mengartikan bahwa petunjuk adalah sebuah kata benda yang dapat bermakna:

a. Suatu tanda atau isyarat yang menunjukkan atau memberitahukan terhadap sesuatu hal;

b. Nasihat atau ketentuan yang memberi arah atau bimbingan sesuatu harus dilakukan;

c. Ajaran;

d. Tuntutan atau ilham.

Pengertian petunjuk adalah suatu perbuatan atau hal yang karena persesuaiannya baik antar satu dengan yang lain, maupun dengan tindak pidana itu sendiri menandakan bahwa telah terjadi tindak pidanan dan siapakah pelakunya, adapun petunjuk tersebut dapat diperoleh dari keterangan saksi, surat dan keterangan terdakwa. Pemberian nilai atas petunjuk tersebut diserahkan kepada kebijaksanaan hakim. ${ }^{13}$

Alat bukti petunjuk menurut Pasal 188 Ayat 1 KUHAP terdiri dari keterangan saksi, surat dan keterangan terdakwa. Sedangkan dalam hukum acara perdata tidak mengenal adanya alat bukti petunjuk. Yang di jelaskan dalam Pasal 164 HIR hanya menyebutkan alat bukti berupa persangkaan-persangkaan yang merupakan kesimpulan-kesimpulan yang oleh undang-undang

\footnotetext{
${ }^{12}$ Hendah Lahyunita, Jurnal Antimonopoli, posting 10 jurnal ke 2.htm, [diakses pada tanggal 20 April 2016]

${ }^{13}$ R. Soesilo.(1997). Kitab Undang-Undang Hukum Acara Pidana dan Penjelasan. Bogor: Politeia, hlm. 167
} 
atau hakim ditariknya suatu peristiwa yang sudah di ketahui (Pasal 1915 KUHPerdata). Jadi persangkaan merupakan alat bukti tidak langsung yang ditarik dari alat bukti lain atau merupakan uraian hakim dengan mana hakim menyimpulkan dari fakta yang terbukti kea rah yang belum terbukti.

Indriyanto Seno Adji menyatakan bahwa alat bukti petunjuk di dunia ini tidaklah dikenal kecuali di Indonesia. Bahkan Belanda sebagai negara yang KUHAP-nya menjadi acuan bagi Indonesia dalam memasukkan pengaturan alat bukti petunjuk pada KUHAP pun telah menghapus ketentuan tersebut sejak 70 tahun yang lalu. Berdasarkan Pasal 42 Undang-Undang Persaingan Usaha, petunjuk merupakan salah satu alat bukti sah yang dapat dipergunakan untuk kepentingan pembuktian perkara. Selain alat bukti petunjuk, pasal tersebut juga menyebutkan alat bukti lainnya yang sah untuk diajukan di persidangan yakni keterangan pelaku usaha, keterangan saksi, keterangan ahli dan alat bukti surat. ${ }^{14}$

Dalam hal ini yang penting untuk diperhatikan adalah peran Majelis Komisi dalam menentukan penggunaan dan menganalisa suatu alat bukti petunjuk tersebut. Majelis Komisi berwenang penuh untuk menentukan sah atau tidaknya suatu alatbukti. Kewenangan menentukan tersebut juga berlaku untuk menentukan sejauh mana suatu bukti dapat dikategorikan sebagai alat bukti petunjuk yang akan digunakan dalam suatu persidangan. Majelis Komisi berhak untuk menentukan apakah suatu bukti dapat dijadikan sebagai alat bukti petunjuk atau tidak.

Pengertian dan kedudukan alat bukti petunjuk dalam arti yuridis haruslah dibedakan dengan petunjuk dalam arti gramatikal. Petunjuk sebagai suatu alat bukti yang sah di suatu persidangan memiliki sifat-sifat di bawah ini, yakni: ${ }^{15}$

1. Selamanya tergantung dan bersumber dari alat bukti lain

2. Alat bukti petunjuk baru diperlukan bila menurut hakim alat bukti lain tak cukup untuk buktikan kesalahan terdakwa. Atau dengan kata lain petunjuk baru dianggap mendesak mempergunakannya apabila upaya pembuktian dengan alat bukti yang lain belum mencapai batas minimum pembuktian.

3. Oleh karena itu hakim harus lebih dulu berdaya upaya mencukupi pembuktian dengan alat bukti yang lain sebelum ia berpaling menggunakan alat bukti petunjuk.

4. Dengan demikian upaya mempergunakan alat bukti petunjuk baru diperlukan pada tingkat keadaan daya upaya pembuktian sudah tidak mungkin diperoleh lagi dari aat bukti yang lain. Dalam batas tingkat keadaan demikianlah upaya pembuktian dengan alat bukti petunjuk sangat diperlukan.

Dari uraian di atas dapat di simpulkan bahwa nilai kekuatan pembuktian dari alat bukti petunjuk bersifat bebas. Hakim tidak terikat atas kebenaran persesuaian petunjuk oleh karena itu hakim bebas menilai dan menggunakannya guna kepentingan pembuktian. ${ }^{16}$

Perjanjian tertulis tidak menjadi keharusan dalam membuktikan adanya suatu perjanjian perilaku kartel, yang diperlukan adalah bukti bahwa kartel secara bersama sama disepakati dan para pelaku usaha mematuhi kesepakatan tersebut, yaitu tidak semata mata berdasarkan alat bukti surat dan/atau dokumen, melainkan dapat juga diperoleh dari keterangan saksi, keterangan ahli, petunjuk, maupun keterangan pelaku usaha. Dalam Perkom No. 4 Tahun 2010 tentang Pedoman Kartel diatur mengenai penggunaan bukti tidak langsung sebagai dugaan telah terjadinya perjanjian kartel atas barang dan jasa oleh pelaku usaha di pasar. Oleh karena itu, Perkom No. 4 Tahun 2010 ini menyatakan bahwa untuk melakukan pembuktian adanya

\footnotetext{
${ }^{14}$ Seno Adji, Indriyanto.(2009.). Korupsi dan Penegakan Hukum. Jakarta: Diadit Media.

${ }^{15}$ M. Yahya Harahap.(2009). Pembahasan Permasalahan Dalam KUHAP: Pemeriksaan Sidang Pengadilan, Banding, Kasasi, dan Peninjauan Kembali. Jakarta: Sinar Grafika, hlm. 317

${ }^{16}$ Ibid.
}

218 Kurniawan | Bukti Tidak Langsung Dalam Penyelesaian.... 
pelanggaran terhadap perjanjian penetapan harga, bukti yang diperlukan dapat berupa bukti langsung (direct evidence), dan bukti tidak langsung (indirect evidence). ${ }^{17}$ Bukti langsung adalah bukti yang dapat diamati dan menunjukkan adanya suatu perjanjian yang dilarang atas barang dan atau jasa oleh pelaku usaha yang bersaing. ${ }^{18}$

Kedudukan bukti tidak langsung dalam Undang-Undang Persaingan Usaha termasuk dalam kelompok bukti petunjuk sehingga menjadi alat bukti tambahan untuk membuktikan dugaan atas pelanggaran Undang-Undang Persaingan Usaha. ${ }^{19}$ KPPU perlu mendapatkan alat bukti lainnya untuk memproses permasalahan hingga didapat suatu kesimpulan akhir atas adanya dugaan pelanggaran UU Persaingan Usaha. Alat bukti tidak langsung tidak dapat digunakan sebagai alat bukti satu-satunya di dalam persidangan yang dilakukan oleh KPPU. Cara penggunaan alat bukti tidak langsung telah dikuatkan oleh Mahkamah Agung dalam putusan kasasi yang diajukan oleh KPPU atas pembatalan oleh Pengadilan Negeri Penggunaan bukti tidak langsung oleh KPPU sebagai alat bukti awal indikator terjadinya kartel yaitu dengan menggunakan metode analisis ekonomi. ${ }^{20}$ Analisis ekonomi dalam beberapa kasus digunakan sebagai alat bukti awal diketahui bahwa ada dugaan praktik kartel. Analisis ekonomi ini berupa analisis dengan menggunakan faktor struktural dan faktor perilaku.

Pada bukti langsung terdapat substansi dari kesepakatan yang dapat berupa bukti fax, rekaman, percakapan telepon, surat elektronik, komunikasi video, dan bukti nyata lainnya. Selanjutnya, bukti komunikasi yang dimaksud adalah bukti-bukti bahwa operator kartel (misalnya) bertemu atau berkomunikasi, tetapi tidak menggambarkan substansi komunikasi mereka. Ini antara lain mencakup, catatan percakapan telepon antara para peserta tersangka kartel, namun tidak termasuk substansi yang sebenarnya dari komunikasi tersebut. Selanjutnya, perjalanan ke tujuan melalui rute umum atau partisipasi dalam rapat. Bukti komunikasi lainnya seperti risalah rapat yang menunjukkan bahwa pemanfaatan harga, permintaan atau kapasitas, dokumen internal yang membuktikan pengetahuan atau pemahaman tentang strategi harga pesaing, seperti prediksi harga di masa depan. Sedangkan bukti tidak langsung adalah bentuk bukti yang tidak secara langsung menyatakan adanya kesepakatan mengenai perjanjian yang dilarang. Bukti tidak langsung dalam perkara kartel dapat digunakan sebagai pembuktian terhadap suatu keadaan yang dapat dijadikan dugaan atas pemberlakuan suatu perjanjian yang tidak tertulis. Bukti tidak langsung dapat berupa bukti komunikasi (namun tidak secara langsung menyatakan kesepakatan) dan bukti ekonomi. Dalam kartel, bukti ekonomi dapat membantu untuk mengidentifikasi pasar cenderung akan cartelized. Dengan bukti ekonomi, dapat membantu untuk membuktikan adanya kartel dengan menganalisis perilaku para pemain di pasar. Namun Masih ada anggapan bahwa penggunaan analisis ekonomi akan menambah biaya dan menambah kerumitan penyelesaian suatu kasus pelanggaran hukum persaingan usaha. Anggapan demikian seharusnya tidak muncul apabila disadari bahwa penggunaan analisis ekonomi pada dasarnya untuk saling melengkapi dengan aspek legal dari penegakan hukum dan bukan untuk mempersulit. ${ }^{21}$

Namun, tidak selamanya analisis ekonomi membutuhkan model dan instrument yang kompleks, tetapi harus disesuaikan dengan kebutuhan suatu kasus. sampai saat ini, penggunaan analisis ekonomi umumnya masih terbatas pada pendefinisian pasar bersangkutan dan penilaian merger. ${ }^{22}$ Penggunaan analisis ekonomi dalam perkara perjanjian horisontal seperti penanganan kasus kartel, relatif masih kurang jika dibandingkan dengan penggunaan analisis

\footnotetext{
${ }^{17}$ www.kppu.go.id, [diakses pada tanggal 10 Mei 2016]

${ }^{18} \mathrm{Ibid}$.

${ }^{19}$ Mutia Anggraeni, Penggunaan Indirect Evidence oleh KPPU Dalam Proses Pembuktian Dugaan Praktek Kartel Di Indonesia, http://.studentjournal.ub.ac.id, [diakses pada tanggal 12 September 2016]

${ }^{20} \mathrm{Ibid}$.

${ }^{21}$ Andi Fahmi Lubis, dkk.(2009). Hukum Persaingan Usaha Antara Teks dan Konteks. Jakarta: ROV Creative Media.

${ }^{22}$ Ibid.
} 
ekonomi dalam pasar bersangkutan dan merger. Suatu bentuk bukti tidak langsung yang sesuai dan konsisten dengan kondisi persaingan dan kolusi sekaligus belum dapat dijadikan bukti bahwa telah terjadi kartel. Analisis ekonomi dalam penegakan hukum persaingan diperlukan untuk menentukan motif dan atau memprediksi dampak dari perilaku (behavior) perusahaan. Analisis ekonomi dalam penentuan motif dan dampak sebuah perilaku yang dilarang di dalam hukum persaingan dapat berupa: ${ }^{23}$

1. Analisis insentif yang digunakan untuk melihat apakah sebuah perusahaan tertarik atau termotivasi untuk melakukan perilaku yang bersifat strategis;

2. Analisis kemampuan yang bertujuan untuk melihat apakah sebuah perusahaan mampu untuk melakukan perilaku strategis yang efektif;

3. Analisis untung rugi yang berperan dalam melihat apakah dampak negatif suatu perilaku strategis lebih besar dari dampak positifnya (jika ada).

Selain itu, dibutuhkan juga suatu analisis tambahan yang dapat dijadikan bukti tidak langsung dalam perkara kartel, yaitu sebagai berikut:

a. Rasionalitas kartel yaitu terdapat paling tidak dua jenis rasionalitas yang harus di buktikan berupa motif yang kuat bahwa kesepakatan kartel menguntungkan bersama dan terdapat alasan yang kuat bahwa tindakan kesepakatan kartel tersebut tidak bertentangan dengan kepentingan perusahaan jika ia bertindak sendiri.

b. Beberapa aspek struktur pasar yang dapat dianalisi diantaranya adalah:

1. Tingkat kemiripan produk

2. Ketersediaan produk pengganti terdekat

3. Kecepatan informasi mengenai penyesuaian harga

4. Standarisasi harga

5. Kelebihan kapasitas

6. Hanya terdapat beberapa perusahaan

7. Hambatan untuk masuk pasar tinggi

c. Analisis data kinerja tinggi diperlukan untuk membuktikan apakah informasi kinerja pasar menggambarkan suatu hasil koordinasi atau kesepakatan.

d. Analisis penggunaan fasilitas kolusi untuk memastikan kesepakatan kolusi dapat dijalankan dan dimonitor, maka para pelaku usaha yang terlibat suatu kolusi akan menggunakan beberapa instrument untuk memfasilitasi suatu kolusi.

Dalam upaya pembuktian, tidak seluruh alat analisis tambahan tersebut diatas harus dipenuhi. Komisi dapat memutuskan bahwa alat analisis tertentu sudah cukup digunakan untuk membuktikan pelanggaran Pasal 11 Undang-Undang Antimonopoli. ${ }^{24}$

Erman Rajagukguk, menyatakan hal-hal yang harus diperhatikan dalam penggunaan Alat bukti tidak langsung adalah sebagai berikut: ${ }^{25}$

a Alat bukti tidak langsung bisa berupa penafsiran atau interpretasi, logika, misalnya beberapa kali mengadakan hubungan telepon tanpa membuktikan isi pembicaraan telepon tersebut, atau beberapa kali mengadakan pertemuan, tanpa membuktikan apa isi pertemuan tersebut

${ }^{23}$ Ibid., hlm. 387

${ }^{24}$ Ibid. 359.

${ }^{25}$ Erman Rajagukguk, Keterangan Ahli Dalam Putusan Pengadilan Negeri Nomor 05/KPPU/2010/PN.Jkt.Pst, hlm. 358-

220 Kurniawan | Bukti Tidak Langsung Dalam Penyelesaian.... 
b Bukti tidak langsung tidak dikenal dalam hukum pembuktian persaingan usaha Indonesia, yang dikenal adalah aat bukti sebagaimana terdapat dalam Pasal 42 UU No. 5 tahun 1999

c Kesimpulannya adalah, bukti tidak langsung tidak sama dengan alat bukti dalam pasal 42 UU No. 5 tahun 1999 dan tidak dikenal dalam Undang-Undang di Indonesia

d Bukti tidak langsung tidak sama dengan alat bukti petunjuk. Berdasarkan Pasal 188 ayat (2) KUHAP, petunjuk harus diperoleh dari keterangan saksi, surat maupun keterangan pelaku usaha / terlapor. Sedangkan bukti tidak langsung bisa berdasarkan dugaan, penafsiran atau interpretasi dan logika. Ketiganya itu dilarang dalam pembuktian tindak pidana di Indonesia sehingga dilarang dalam perkara persaingan usaha yang menganut prinsip-prinsip dalam hukum pidana.

e Bukti tidak langsung berasal dari beberapa kasus di luar negeri. Akan tetapi, prinsip pembuktian yang diterapkan dalam putusan kasus-kasus luar negeri baru bisa dipergunakan di Indonesia, bila prinsip-prinsip tersebut sudah dianut oleh undang-undang nasional Indonesia. Dalam segi formal sebagaimana tertuang dalam pertimbanganpertimbangan putusan Pengadilan Negeri, memang Indonesia tidak menganut metode pembuktian tidak langsung, tapi melihat kasus kartel sulit mencari dan menemukan bukti langsung seharusnya dimungkinkan menggunakan metode pembuktian tidak langsung. Secara logika berfikir terhadap kasus kartel, pada faktanya kartel menjadi begitu sulit dideteksi tanpa menggunakan karena perusahaan yang berkolusi berusaha menyembunyikan perjanjian diantara mereka untuk menghindari kejaran hukum.

Dari bentuk pembuktian, baik langsung maupun tidak langsung seharusnya dalam menerapkan suatu prinsip hukum terutama dalam perkara persaingan usaha tidak melihat dengan kaku dan terbatas, karena hukum persaingan usaha itu sendiri sifatnya sangat dinamis dimana berkembang sesuai dengan perkembangan ekonomi dan kebijakan suatu negara.

\section{KESIMPULAN}

Dari uraian yang dikemukakan pada bab pembahasan, maka dapat ditarik simpulan bahwa kedudukan bukti tidak langsung dalam Undang-Undang Persaingan Usaha terkait perkara kartel sifatnya hanya sebagai bukti tambahan saja. Bukti tidak langsung tidak dapat dijadikan satu-satunya alat bukti dalam penanganan perkara kartel oleh KPPU. Bukti tidak langsung dalam Undang-Undang Persaingan Usaha merupakan bagian dari bukti petunjuk, sehingga yang termasuk dalam alat bukti adalah bukti petunjuk sebagaimana terdapat pada Pasal $42 \mathrm{UU}$ Persaingan Usaha, sedangkan bukti tidak langsung berupa bukti komunikasi atau hasil analisis ekonomi yang digunakan merupakan bukti tambahan untuk memperkuat alat bukti petunjuk.

\section{DAFTAR PUSTAKA}

\section{Buku}

Fahmi Lubis, Andi.(2009). Hukum Persaingan Usaha Antara Teks dan Konteks. Jakarta: ROV Creative Media.

Harahap, Yahya.(2009). Pembahasan Permasalahan Dalam KUHAP: Pemeriksaan Sidang Pengadilan, Banding, Kasasi, dan Peninjauan Kembali. Jakarta: Sinar Grafika. 
Ibrahim, Johnny.(2007). Hukum Persaingan Usaha. Malang: Bayumedia Publishing.

Mustafa Kamal Rokan.(2010). Hukum Persaingan Usaha. Jakarta: PT RajaGrafindo Persada.

Munadiya, Riris.(2011) "Bukti Tidak Langsung (Indirect Evidece) Dalam Penanganan Kasus Persaingan Usaha”. Jurnal Persaingan Usaha. 5.

Rajagukguk, Erman. Keterangan Ahli Dalam Putusan Pengadilan Negeri Nomor 05/ KPPU/2010/PN.Jkt.Pst.

Siswanto, Arie.(2002). Hukum Persaingan Usaha. Jakarta: Ghalia Indonesia.

Sitompul, Asril.(1999). Praktek Monopoli dan Persaingan Usaha Tidak Sehat. Bandung: Citra Aditya Bakti.

Seno Adji, Indriyanto.(2009). Korupsi dan Penegakan Hukum. Jakarta: Didit Media.

\section{Peraturan Perundang-Undangan}

Indonesia, Undang-Undang Dasar Negara Republik Indonesia Tahun 1945.

Indonesia, Undang-Undang Nomor 5 Tahun 1999 tentang Larangan Praktek Monopoli dan Persaingan Usaha Tidak Sehat, LN No. 33 Tahun 1999, TLN. 3817.

Peraturan Nomor 1/KPPU-I/2010 tentang Tata Cara Penanganan Perkara Berdasarkan UU Antimonopoli.

Peraturan Komisi Pengawas Persaingan Usaha Nomor 4 Tahun 2010 tentang Pedoman Pelaksanaan Pasal 11 UU Larangan Praktek Monopoli dan Persaingan Usaha Tidak Sehat.

\section{Internet}

Anggraeni, Mutia. Penggunaan Indirect Evidence oleh KPPU Dalam Proses Pembuktian Dugaan Praktek Kartel Di Indonesia, http://.studentjournal.ub.ac.id/, diakses pada tanggal 1 April 2016.

Lahyunita K, Hendah, Jurnal Antimonopoli, posting 10 jurnal ke 2.htm, diakses pada tanggal 20 Maret 2016

Messi, Nawir, Menakar Kekuatan Circumstantial Evidence di Persainga Usaha, hukum online. com.htm, diakses pada tanggal 27 Januari 2016. 